\title{
OPPORTUNITIES FOR MULTIPLYING THE EXPENSES IN ECONOMIC EFFECTS AND BENEFITS FOR THE BUDGET OF THE NATIONAL MILITARY UNIVERSITY "VASIL LEVSKI"
}

\author{
Pavlin Ivanov GLUSHKOV \\ "Vasil Levski" National Military University, Veliko Turnovo, Bulgaria \\ pavlin_glushkov@mail.bg
}

\begin{abstract}
In recent years, there is a marked tendency for the net amount of salaries, social security payments, social expenses and scholarships at the National Military University "Vasil Levski" to increase. This is due both to an increase in the number of staff on a permanent employment contract and the number of cadets, and to the change in the parameters of the average annual gross salary and scholarships, as well as the structure of the compulsory social security contributions.

It can be concluded that in view of the increase in the number of cadets over the last few years, there will be a tendency for the net share of salaries, remunerations, social contributions, social expenses and scholarships to increase in the future.

Opportunities to remedy the imbalances in the cost structure of the National Military University "Vasil Levski" can be found not only in the increase of the money supply in the transfer and the increase in the university's revenues, but also in the optimization or improvement of the expenditures as regards benefits and support.
\end{abstract}

\section{Keywords: budget, economic, effects, efficiency, military}

\section{Introduction}

Security and defense viewed as a public good or public need draw funds from public finances, namely the government budget.

Military expenditures are one of the most significant and resource-consuming items of government budgets. Their importance is due to their impact on budget balances, government borrowings and debts, the triggering of inflation, the rise in taxes and other factors.

The Ministry of Defense (MoD) is the firstlevel budget spending unit, which is designated by law and, as such, prepares a draft budget, manages its implementation, controls the processes of planning, drafting, implementing and reporting of the budgets of the secondary budget spenders from the lower level.
The Head of the NMU "Vasil Levski" [22] was appointed as a secondary budget spender with the Minister of Defense, the result of which being that the obligation for the supply of material resources and services outside the centralized system of the Ministry of Defense should be carried out pursuant to the Public Procurement Act. As a result, contracts for the supply of material resources and services are signed.

\section{Exposition}

The National Military University "Vasil Levski" (NMU) provides education to cadets and students to acquire higher education qualification for the Bachelor's and Master's degrees. The university provides education for cadets, students, postgraduates and $\mathrm{PhD}$ candidates. The cadets are admitted at the University to be trained for the needs of the 
armed forces. For the duration of their training, they are considered military personnel with a special status of trainees, and are preparing for the practice of military service as a profession [23].

It is the mission of the University to build moral, mental and physical qualities in its graduates and postgraduates, to cultivate in them the ideals of patriotism, duty and honor, to build them as personalities and leaders capable of developing and applying scientific knowledge, of managing public and special structures in peacetime and in crises, of participating in national and multinational projects to maintain security and to protect the peace and development of society [12].

The predominant age group of the trainees at the NMU is between 19 and 23 years.

The cadets sign military service contracts, the term of which includes the duration of the training. Full state funding is provided for the duration of the training of the cadets at the higher military schools [17].

Expenses for ongoing support include medication, bedding and clothing, materials, food, water, fuels, energy, missions, spare parts, and so forth.

An Act of the Minister of Defense, regulating the conditions, rules and norms of providing free food and refreshing beverages to the military and civilian personnel at the Ministry of Defense, to the structures in direct subordination to the Minister of Defense and the Bulgarian Army, and to the cadets in the higher military schools in peacetime, explicitly stipulates that the cadets are entitled to free daily meals for the duration of their training [20].

The ongoing expenses necessary for the support of the structures of the NMU are determined taking into account the following features [13]:

Expenses - The amounts of the necessary financial resources for ongoing support of the University structures are planned in the Program Memorandum, taking into account the expected organizational changes within the programming period.
- The annual, monthly, daily and hourly resource consumption norms are determined on the basis of the current regulatory documents in force at the MoD, and the approved curricula and programs.

Regarding the planning and provision of financial resources for the provision of food to the cadets, the following factors are important: the number of cadets enrolled at the university; the number of places declared for admission for the respective year; the number of detached personnel; and the maximum amount of the monetary value of the recommended basic foodstuffs in the provision of free food to the cadets at the higher military schools, as announced by an order of the Minister of Defense [20]. The report on the cash management implementation of the budget [21] of the NMU - Veliko Tarnovo, as of 31.12.2016, shows total expenses for ongoing support amounting to BGN 3374559.

These expenses represent approximately $20 \%$ of the reported total costs for the year, which amounted to BGN 16902 507. This represents a significant financial portion of the available funds for the year. The importance of the amount of ongoing expenses for an institution - a secondary spender of budget credit, such as a NMU, can be determined by looking at the rest of the cost structure. The largest and most significant element of the University's expenses is the expense incurred by: paying salaries and remunerations to the personnel employed under employment and service contracts - BGN 7476 807; other remunerations and payments for the personnel - BGN 2092 084; social security payments - BGN 2908 498. The total sum of the expenses for remuneration and social security contributions amounts to BGN 12 477389 , representing approximately $73.8 \%$ of the reported expenses for the year. Social expenses and scholarships for 2016 amounted to BGN 942832 , or approximately $5.5 \%$ of the reported expenditures for the year. The total amount of wages, salaries, social security contributions, social expenses, scholarships 
and support represents $99.3 \%$ of the reported expenditures for the year. In this context, the available resource for expenditures contributing to the development of the educational facilities amounted to approximately $0.7 \%$ of the reported expenditures for the year. The development of the educational facilities can be considered in terms of implementing major repairs of fixed tangible assets, acquisition of fixed tangible assets, acquisition of fixed intangible assets.

The costs of fixed tangible assets in secondary spenders of budget credit may include the acquisition of: computers and hardware; buildings; other equipment, machinery and facilities; vehicles; business inventory; infrastructure sites; other fixed tangible assets.

The costs of fixed intangible assets in secondary spenders of budget credit may include the acquisition of: software products and licenses for software products; other intangible fixed assets. An economically sound, proportionate and rhythmic acquisition of fixed assets from NMU would be a significant step in multiplying initial costs into economic effects and benefits for the budget, both in the short and long term. The targeted investment in intellectual property, educational facilities and infrastructure for leisure activities, recreation and rehabilitation of the students will undoubtedly contribute to the positive development of important indicators directly related to the expert evaluation in the context of the Rating system of higher education institutions in the Republic of Bulgaria, but will also have a direct bearing on the users of the educational services at the NMU.

The rating system [9] is important for the implementation of policies such as the synchronization of higher education with the needs of society and the labor market. It is also a key factor in improving the structure and effectiveness of higher education in Bulgaria. The latest amendments to the Higher Education Act and the new model for determining the planned intake of students are aimed at enhancing the quality of higher education and correlating it with the needs of the economy and society, and by 2020 the funding on the basis of quality should rise to $60 \%$.

Figure 1 shows the absolute values of the indicators - group "Learning Environment" of the Rating System in the professional field of "Administration and Management" of the NMU for the year 2016. The above mentioned group includes the following indicators - evaluation of the library's collection, evaluation of the facilities and satisfaction with the learning environment. The data shows that, under the three indicators, there is a downward trend from the peak years (2013 and 2014), with the evaluations reaching average and lower levels in 2016. Evaluations are given on a scale of $0-10$.

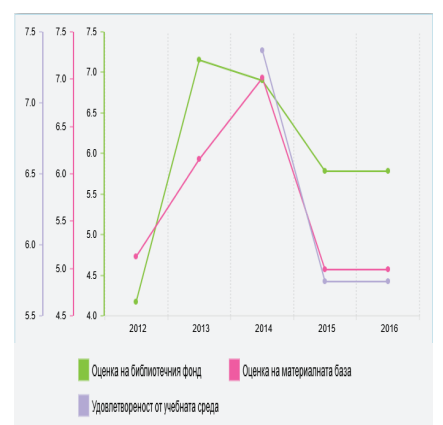

Figure 1: Diagram [10] shows the absolute values of the indicators - group "Learning Environment" of the Rating System in the professional field of "Administration and

Management" of the NMU for the year 2016

If a comparison is drawn between NMU and the American University in Bulgaria Blagoevgrad (AU), which is among the leaders in the professional field "Administration and Management", it will be seen that NMU is far lower in the evaluations of the different indicators. The data for $\mathrm{AU}$ is shown in Figure 2. 


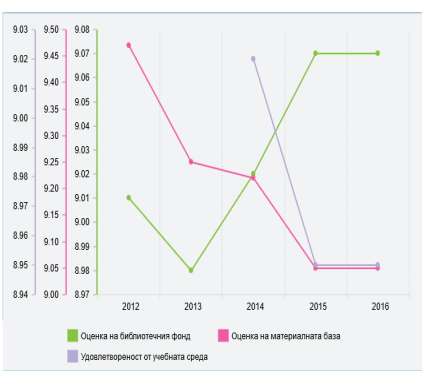

Figure 2: Diagram [11] shows the absolute values of the indicators - group "Learning Environment" of the Rating System in the professional field of "Administration and Management" of the AU for the year 2016

The evaluations of the indicators between the two Higher Education Institutions are predominantly in favor of the $\mathrm{AU}$, as shown in Figure 3. According to data provided by the Ministry of Education and Science [9], the taxable income of graduates from the "Administration and Management" professional field at the AU is distinguished by a monthly average of over BGN 3,000.

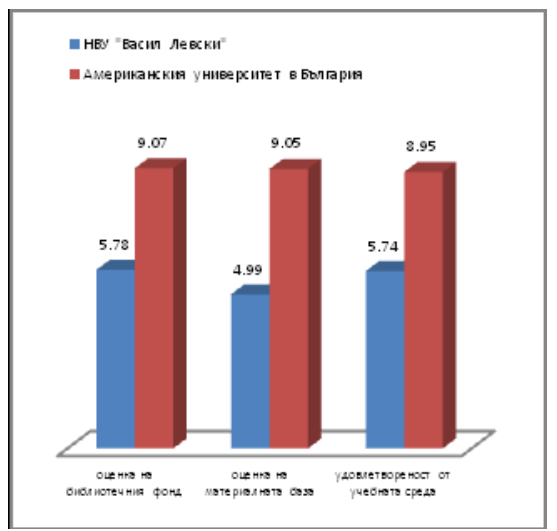

Figure 3: Comparison of the evaluations of the indicators between "NMU and AU for 2016

According to data provided by the Council of Ministers of the Republic of Bulgaria [18], for the construction, maintenance and development of the defense capabilities of the Armed Forces, by 2020 the cost structure should be as follows: staff expenses $-60 \%$, ongoing expenses - $20 \%$ and capital expenses - 20\%. In 2016, the level of these expenditures in the Ministry of Defense and the Bulgarian Army (excluding the military schools) was as follows: staff expenses - $64.6 \%$, ongoing expenses - $23.4 \%$ and capital expenses $12 \%$. The imbalances between the planned expenses by 2020 , the achieved results in 2016 at the Ministry of Defense and the Bulgarian Army and the factually reported expenses incurred by the NMU are obvious. The optimization of expenses is a powerful tool to influence the emerging imbalances in the near future.

The optimization of expenses incurred by organizing, preparing and delivering readyto-eat food would be a significant contribution to changing the structure of the future budgets of the "Vasil Levski" NMU. This is supported by the possibility of reducing the huge amount of money that is planned to be spent within the framework of the signed public procurement contract № 2095 / 28.05.2015 for the implementation of the preparation and distribution of food.

The students at NMU fall into the first age group (19 to 30 years) of the adult population, as specified in the Food based dietary guidelines for adults in Bulgaria [19]. The funds provided for in the annual budgets of the University for the organization, preparation and delivery of ready-to-eat food are an element of the full state funding for the students. The nature of these expenses implies that they relate to the ongoing expenses for the support of the students. An Act of the Minister of Defense, regulating the conditions, rules and norms of providing free food and refreshing beverages to the military and civilian personnel at the Ministry of Defense, to the structures in direct subordination to the Minister of Defense and the Bulgarian Army, and to the cadets in the higher military schools in peacetime, explicitly stipulates that the cadets are entitled to free daily meals for the duration of their training [20].

According to the specification [24] for the provision of food for cadets, servicemen, participants in field exercises and officials on duty for the period between 01.06.2015 and 31.05.2019, the University is expected to incur expenses amounting to BGN 5884 549. Part of this amount, amounting to BGN 1090 003, which represents 18.5\% of 
the total amount allocated for food expenses, is planned for the payment of overheads (a constant value, according to the contract). The rest of the sum, amounting to BGN 4794 546, is earmarked for food products for the preparation of food, in accordance with the stipulated norms [20]. It is this considerable amount of money that is subject to revision. The opportunities for optimizing food costs can be sought in science-based approaches to determine the nutritional status of the cadets, the average daily energy expenditure and the nutritional needs of the body, and, based on the results obtained, adequate nutrition standards should be developed. A body of research done in this direction $[3,4,5,6,7,14]$ gives us grounds to expect a reduction in the cost of food for cadets and the subsequent release of a significant financial resource to be managed by the head of the NMU.

The efficiency and effectiveness of logistics processes is directly related to the principle of cost-effectiveness through the correlation between "costs and benefits" [16]. This correlation is also studied by other authors looking for energy efficiency solutions $[1,2]$.

The development of the national and international legislations in the sphere of nutrition of the different demographic groups, as well as recent studies in the field of rational and healthy nutrition, provide new opportunities and are a strong prerequisite for identifying more favorable solutions in the supply of food for NMU cadets.

\section{Conclusion}

The provision of food in a resourcerestricted environment should be done in accordance with the principles of logistics. The logistics doctrine defines efficiency in the following way: "Logistics resources should be used as efficiently and economically as possible. Needs must be identified in good time, with a view to optimizing their provision and use in a resource-restricted environment. Furthermore [15], it ought to be said that in the theory and practice of corporate management, efficiency is seen as a fundamental economic category. It reflects the cause-and-effect relationships in terms of quantity and quality between the results and the costs or resources for their attainment.

Economic efficiency is a characteristic of economy and is traditionally defined as the ratio between the results obtained and the costs incurred, or vice versa. Moreover, efficiency finds expression in the performance of the least resourceconsuming activities [8].

The efficiency of the supply of food is directly dependent on certain requirements, the more significant of which are [15]: the application of scientifically based nutrition norms; the achievement of a balanced and healthy nutrition; the use of foods that are favored by the cadets, allowing for the preparation of favorite dishes and achieving greater satisfaction; the application of a nutritional model adequate to the needs of the cadets; economy.

\section{References}

[1] Banabakova V., Filipov S., Stoyanov S., State and Problems of Warehousing of Bulgarian Army, International conference Knowledge-Based Organization, Volume XXIII No 2, pages 9-15, Sibiu, Romania, 2017.

[2] Filipov S., Price Analysis of Different Options for Thermal Insulation of Vasil Levski National Military University Headquarters, Buletin Stiintific, Vol. 22 Issue 2, pages 86-90, Sibiu, Romania, 2017.

[3] Glushkov P., A study of nutrition and the nutritional status of servicemen, assessed on the basis of anthropometric indicators, International conference Knowledge-Based Organization, Volume XXIII No 2, pages 298-302, Sibiu, Romania, 2017. 
[4] Glushkov P., Use of linear optimization model in defining the new standards for the preparation of food for servicemen in preparation for participation in peacekeeping operations, International conference Knowledge-Based Organization, Volume XXIII No 2, pages 65-70, Sibiu, Romania, 2017.

[5] Nichev N., Possibility for Improving the Planing of the Needs of Food from Bulgarian Army Units When Participating in Humanitarian Operations, Revista Academiei Fortelor Terestre, Vol. XXII, Nr. 1 (85), pp. 18-24, Sibiu, Romania, 2017.

[6] Stefanov N., Analysis of the Use of Outsourcing Services for Maintenance and Repair of the Equipment and Armament Available in the Structures of the Bulgarian Armed Forces, International conference Knowledge-Based Organization, Volume XXIII No 1, pages 467-472, Sibiu, Romania, 2017.

[7] Stefanov N., Analysis of Some of the Applicable Outsourcing Services in the Structures of the Bulgarian Armed Forces, International conference Knowledge-Based Organization, Volume XXIII No 1, pages 473-478, Sibiu, Romania, 2017.

[8] alternativi.unwe.bg/alternativi/br4/15\%20-\%20Hristov_statia_br.4.doc, c. 6

[9] https://mon.bg/?go=news\&p=detail\&newsId=2295

[10] http://rsvu.mon.bg/rsvu3/\#UniSinglePlace:ZFxefF0

[11] http://rsvu.mon.bg/rsvu3/\#UniSinglePlace:ZFZQfF0

[12] Административен модел на НВУ „Васил Левски”, ISBN 978-954-753-084-3, с. 62, 2012.

[13] Вътрешни правила на системата за финансово управление и контрол, В. Търново, ISBN 978-954-753-083-6, 2012.

[14] Глушков П., Сравнение на нормативната база за хранене на населението с нормите за хранене за сили при подготовка за експедиционни операџии, Научна конференция на НВУ “В. Левски”, ISSN 2367-7473, с. 86-91, 13-14 ноември 2014.

[15] Глушков П., Възможности за усъвършенстване на осигуряването с материални средства клас I на формированията от Българската армия, участващи в експедищионни операщии, Дисертация, ИК НВУ “В. Левски”, с. 218, 2017.

[16] Димитрова С., Управление на ресурсите за отбрана в сектора за сигурност. Велико Търново, ИК НВУ „В. Левски“, с. 8, 2011.

[17] Закон за отбраната и въоръжените сили на Република България, Обн., ДВ, бр. 35 от 12.05.2009 г.

[18] Министерски съвет на Република България, Доклад за състоянието на отбраната и въоръжените сили за 2016 г., София, с. 15, юли 2017.

[19] Наредба № 23 от 19 юли 2005 г. за физиологичните норми за хранене на населението, Министерство на здравеопазването, обн. дв. бр.63 от 2 август 2005.

[20] Наредба № H-5/02.04.2015 г., МО, 2015.

[21] Отчет за касовото изпълнение на бюджета на Национален военен университет “Васил Левски” - гр. Велико Търново към 31.12.2016 г., http://www.nvu.bg/node/1815

[22] Постановление на Министерски съвет № 143 от 09 юли 2002 год., обн. в ДВ бр. 68 от 2002 год.

[23] Правилник за устройството и дейността на Националния военен университет "Васил Левски", Приет с ПМС № 200 от 11.09.2003 г., обн., ДВ, бр. 83 от 19.09.2003 г.

[24] НВУ “Васил Левски”, Документаџия за участие в открита процедура за възлагане на обществена поръчка при условията на глава пета от закона за обществените поръчки - кетарингово хранене, с. 85-91, 2015. 